既に発表した被写体の厚さと所要放射量の 関係式 $\mathrm{I}=\mathrm{K}\left(\mathrm{D}^{3}+\alpha\right)$ を用いて $\mathrm{D}=1 \mathrm{~cm} \sim 30 \mathrm{~cm}$ に対する $\mathrm{I}$ を計算し，その露出系数を求めた，是に距離自乗，電 圧逆 4 采の二法則を加味することによって，人体の何 処でも1 1 所の撮影条件を知って居れば他の何れの部 位でも写すことが出来る。

（第 6 回総会発表）

[63]

\section{露出条件決定を目的とする電圧表の検討とそ の更正に就て}

大阪府立大阪病院 梅谷友吉 露出条件決定に管電圧の定常性は重要であり，之は 電压表のみに依存するととは危険である，成因の如何 にかかわらず管電圧の変動を予想しつつ電圧計の読み に対する射出X線の硬度をべノアの硬度を以て常に記 録し来り永年間に不測の変動を明かにした。

（第 6 回総会発表）

[64]

\section{第一次胸部攝影に於ける最適管電圧の決定に 関する考察}

大阪府立大阪病院 梅谷友吉 一次撮影（仮称）に於いて理論的，並に粉末キルク 層及び水槽を以て構成なしたる人工肺吸収層の撮影又 透過線量の測定等実験的結果より，肺野に包含せらる る対象の吸収率が周囲と僅少なる差を示す場合，或は 小さい（薄い）対象である場合，被写体の厚さを因子 に含めて最適とする管電圧に就いて考察した結果を報 告.

（第 8 回総会発表）

$[65]$

\section{路出表に就いて}

阪大医学部 内田 勝

科学的撮影法の一環として,蓕に露出表を発表した。 本露出表は理論をもととし，簡単な実験によって作ら れたものである, その理論，製作法，吟味，結果につ いて記述した。

（第 7 巻第 $2 \cdot 3$ 号掲載）

[66]蕃放式 X線装置による一般外科撮影の露出表 に就いて

大阪大学医学部 内田勝

演者はさきに「蓄放式X線装置の露出表に就いて」 と題して主に胸部撮影に於ける露出表に関してレント ゲン講坐誌上に報告した。ととには一般外科撮影の露
出表に就いて報告する。一般外科撮影に関しては部位 厚が狭い範囲の胸部等価軟部組織厚と異なり広範囲に 亘る為 1 本の直線で近似せしめる事は不当で先ず理論 的に等線量曲線を求め実験によりそれを確証し実用的 な露出表の製作をなし得たので報告.

（第 8 回総会発表）(第 8 巻第 1 号掲載）

\section{〔67]各程係数攝影法の実験的比較}

阪大医学部井川稔

科学的撮影法として今迄各種の係数撮影法が発表さ れ各々検討が加えられて来たが筆者はこれを類別して 次の三つ即ち，アメリカ法，綱川氏法，内田氏法に就 いて実用的見地から比較検討した。

(第 9 回総会発表)

\section{〔68】肺藌摄影に関する基本的諸問題の検討}

結核予防会 網川高 美

現実の問題としては肺内に在る (A) $1 \mathrm{~mm} の$ 病巣が フィルム上に表現されることである．次に(B) $10 \mathrm{~mm}$ の病巣は脑野の何れに在っても撮り落してはならな い. 又 $(\mathrm{C}) 1 \mathrm{~mm}$ の病巣の集合と $10 \mathrm{~mm}$ 単独病巣と の判別がつかなければならない。との三つの撮影目標 に対する手技の選定は対照度尖鋭度，像の重なりの三 面方から検討して行くべきである。

今回は主として头鋭度に就て検討した。各種の装置 増感紙に就て撮影条件が合理的ならばフィルム上のボ ケの平均值は $0.79 \sim 0.94 \mathrm{~mm}$ 位で $\mathrm{A}, \mathrm{B}, \mathrm{C}$ 何れの目 標に対しても充分な尖鋭度が得られることが分った。

（第 9 回総会宿題報告）

[69]病巣 (吸出体) の種々相を摄影目標となした る場合の胸部 $\mathbf{X}$ 線骤影術式に関する実験的研究 大阪府立大阪病院 梅谷友吉

演者は第 8 回総会に於て第一次胸部 $\mathrm{X}$ 線写真の管電 圧として V = logd $\times 64+1(\mathrm{KVp})$ なる式を得た事を報 告したが今回は之を再検討して前式を補正すると共に 之が在来の胸部 X線写真とは概念を新にして論議すべ きであり，余の実験経過より撮影手技が濃度並に単な う対照度のみにこう泥せる従来の露出手技やアメリカ 式系数撮影法に於てみる影像の実態を顧みるととの重 要さを痛感するに至り，如何なる程度の病单を如何に 军出すべや又なし得べやについて技術的臨床的に 其の限界值の如き一線を画し得るとせば将来装置の改 良と相まって胸部 $\mathrm{X}$ 線撮影手技の新生面たるを信じ， 